\title{
Dirk Westerkamp \\ Quaestio sceptica disputata de philosophia judaeorum: Is there a Jewish Philosophy?
}

\author{
Listen to the truth whoever speaks it. \\ (Maimonides, Eight Chapters)
}

\section{Quaestio}

The question reads: Is there a Jewish Philosophy (JP) or Can there be a JP? This question evidently entails the question: What is JP?

\section{Videtur quod}

It seems that there is a JP. JP is taught at departments of philosophy and Jewish thought around the world. JP looks back on a long history and rich tradition. Sometimes JP is put to use in public debates. ${ }^{1}$ We speak of Philo, Maimonides, Mendelssohn and Lévinas as Jewish thinkers. JP is a philosophical tradition and we should not underestimate that traditions are important for (the history of) philosophy. ${ }^{2}$ They are constituents of philosophical discourse and the simple fact that they emerge, change or come out of fashion over time does not imply that they don't exist or do not matter. So, yes, arguably there is such thing as JP.

1. However, since ontological, epistemological and methodological matters do not seem to be determinable as specifically 'Jewish', Tirosh-Samuelson/Hughes argue that JP is not primarily a theoretical enterprise but a practical philosophy 'heavily invested in matters of Jewish peoplehood and in articulating its aims and

\footnotetext{
Paper given at the Dialectical Evening at the Maimonides Centre for Advanced Studies, Universität Hamburg, August 22, 2017. Many thanks to all its participants for the helpful comments and the lively discussion. In order to encourage a debate this paper was presented in the form of a scholastic quaestio. It should be noted, however, that this is a kind of sketch. Neither do I want to pretend that it is a bona fide Quaestio in the formal scholastic sense; nor do I think that this stylised form of a Quaestio is the best and only way to discuss this matter. I trust that the irony of its presentation does not distract from the seriousness of the arguments.
}

1 Cf., e.g., Eliezer Schweid, New Gordonian Essays: Globalization, Post-Modernism, Post-Humanism and the Jewish People [in Hebrew] (Tel Aviv: Hakibbutz Hameuchad, 2005).

2 Josef Stern, "What is Jewish Philosophy? A view from the Middle Ages," in Yearbook of the Maimonides Centre for Advanced Studies 2017, ed. Bill Rebiger (Berlin and Boston: De Gruyter, 2017): 199. 
objectives.' 3 To this aim, it constantly and always had to apply ideas of 'non-Jewish' origins 'to Jewish ideas and values." Thus, JP is 'in tune with certain principles of rationalism."

2. JP aims at harmonising philosophy and the Jewish tradition; ${ }^{6}$ JP agrees with the 'Jewish religious tradition.' JP 'explain[s] and rationalize[s]' the 'essential core of Judaism.' Complementary to this essentialist account, the formalist account of JP maintains that

- JP is 'any philosophy produced by a Jewish person, whatever the definition given for "Jewish"'8 (= necessary condition);

- JP has to address Jewish issues to define a philosophy as Jewish (= sufficient condition): 'While essentialism focusses on the Jewish content, moderate formalism rather takes into account the Jewish context."

3. It seems that there is JP as long as JP matches the standards of philosophical discourse: analysis, argument, distinction, critical evaluation, problem-solving. ${ }^{10}$ Likewise, Melamed argues that the reality

[...] for modern Jewish philosophy was that most of its participants were either good philosophers (Spinoza and Cohen) or well informed in Jewish texts (Mendelssohn, Krochmal, Soloveitchik), though unfortunately in many cases they were neither Jewishly informed nor good philosophers. ${ }^{11}$

Thus, there can be JP if it meets the-given-standards of state of the art philosophy (that seems to be one of the differences between JP and Jewish Thought, JT) plus the standards of erudite scholarship in Jewish studies. As for Modern JP, then, it seems that the 'real question is not "Is there a Jewish Philosophy?"' but: 'Is Jewish philosophy (still) philosophy?'12 On this view, there can also be an Analytic Jewish Philos-

3 Hava Tirosh-Samuelson and Aaron W. Hughes, "Editors' Introduction to Series," in Eliezer Schweid: The Responsibility of Jewish Philosophy, Library of Contemporary Jewish Philosophers, vol. 1, eds. Hava Tirosh-Samuelson and Aaron W. Hughes (Leiden and Boston: Brill, 2013): xi.

\section{Ibidem.}

5 Ibidem, xii.

6 Raphael Jospe, Jewish Philosophy: Foundations and Extensions, vol. 2: On Philosophers and Their Thought (Lanham: University Press of America, 2008), 20.

7 Stefan Goltzberg, "Three Moments in Jewish Philosophy," Bulletin du Centre de recherche français à Jérusalem 22 (2011): 1.

8 Raphael Jospe, “Teaching Judah Ha-Levi: Defining and Shattering Myths in Jewish Philosophy,” in Paradigms in Jewish Philosophy, ed. Raphael Jospe (London: Associated University Press, 1997): 113. 9 Goltzberg, "Three Moments in Jewish Philosophy," 2.

10 See Stern, "What is Jewish Philosophy? A view from the Middle Ages," 189.

11 Yitzhak Melamed, "Salomon Maimon et l'échec de la philosophie juive modern," Revue germanique internationale 9 (2009): 186-187.

12 Josef Stern, "Was jüdische Philosophie sein könnte (wenn es sie gäbe). Ein mediävistischer Blick,” Zeitschrift für Kulturphilosophie 11 (2017): 296. 
ophy applying the tools of logical and conceptual analysis for example to talmudic reasoning ${ }^{13}$ or to Wittgensteinian accounts of lifeforms. ${ }^{14}$

4. In this sense, we may speak of JP if it is (i) philosophy (in the above mentioned sense) and (ii) concerned with Jewish religious and cultural practices. Melamed seems to adhere to the essentialist rather than to the formalist account of JP:

Unlike many others, I do not take a Jewish philosopher to be someone who is (a) Jewish and (b) a philosopher, but rather suggest that Jewish philosophy is the attempt to provide a well-argued and informed account of Jewish religious and cultural beliefs and practices. ${ }^{15}$

Being Jewish, then, would neither be a necessary nor a sufficient condition for doing JP whereas providing an 'account of Jewish religious and cultural beliefs and practices' would be the necessary condition.

5. JP is the philosophy of Judaism; it is 'invested in matters of Jewish peoplehood,' 'in tune with certain principles of rationalism,' and providing an 'account of Jewish religious and cultural beliefs and practices.' It is contested, however, as to whether this essentialist account of JP has to be critical as well-meaning that it should critically reflect JP's own historicity: 'The critical approach takes into account the history of the texts, their modification over time, their successive editions. This critical approach is philosophically and historically receivable.' From the non-critical essentialist's point of view, 'a text of Jewish philosophy does not have to meet the criteria of the critical approach.'16

6. According to the critical essentialist view, JP and JT form a 'dynamic space of thought' (dynamischer Denkraum), ${ }^{17}$ consisting of three 'spatial' elements: philosophy, mysticism, and theology. This space, however, is systematically nuanced, thematically inclusive (there can be more, for example the musar-movement etc.), and interculturally open. This essentialist view of JP is critical insofar as it holds that the essence of JP (and Judaism) is not static and stable but in constant transition, antithesis, and dynamic.

7. Furthermore, the critical essentialist account of JP can be divided into two camps: (i) Either JP fully (though not without self-criticism) endorses, promotes and defends Jewish beliefs, practices and convictions; or (ii) JP aims at being rather a 'philosophy of Judaism,' implying that JP seeks to 'achieve a critical understanding

13 Cf., e.g., Eli Hirsch, "Identity in the Talmud," Midwest Studies in Philosophy 23 (1999): 166-180.

14 Cf. Hilary Putnam, Jewish Philosophy as a Guide to Life: Rosenzweig, Buber, Levinas, Wittgenstein (Bloomington: Indiana University Press, 2008).

15 Melamed, “Salomon Maimon et l'échec de la philosophie juive modern,” 176.

16 Goltzberg, “Three Moments in Jewish Philosophy," 4.

17 Frederek Musall, “Jüdisches Denken denken," in Jewish Lifeworlds and Jewish Thought (FS Grözinger), ed. Nathanael Riemer (Wiesbaden: Harrassowitz, 2012): 141-149. 
of the foundational beliefs, logical structure, and presuppositions articulated in its data, not to promote them.'18

8. Some currents of the second strand of critical essentialist account of JP can be interpreted as negativistic. On this view, we better not define the critical essence of JP in positive terms (since its Denkraum is systematically and historically open and shifting). Rather, it can be determined through negative distinctions. According to the negativistic critical essentialist account, JP is

- not a school (for example Kalam; Aristotelians, Neo-Platonists),

- not a style (analytic philosophy, phenomenology, hermeneutics),

- not philosophy done by Jews (not an ethnic category),

- $\quad$ not philosophy written in Hebrew. ${ }^{19}$

Some positive attributes, however, can be formulated. Medieval JP, for instance, was a network of a 'continuous dialogue' of Jewish authors 'embedded' in the 'tradition of Islamic philosophy and its Greek sources' and, later, encountering Christian scholastic philosophy. ${ }^{20}$ Within this discourse-network, the question of the relation between Philosophy and Torah is debated. JP is 'a causally-intraconnected discourse, or conversation, what I called a "tradition"”21 following the agenda of discussing the relation between philosophy and Torah set by Maimonides' Guide.

\section{Sed contra}

On the other hand, the existence of a JP is heavily contested, abrogated, and denied. To highlight this, let me report a somewhat funny, yet illuminating personal conversation I had with one of my academic advisors, Yossef Schwartz, while returning to the Hebrew University of Jerusalem as a Visiting Research Fellow (in 2000):

Schwartz: 'What do you want to study with me while you are a Visiting Research Fellow at the Hebrew University?'

Westerkamp: 'Medieval Jewish Philosophy.'

Schwartz: 'Ein davar-there is no such thing as Medieval Jewish Philosophy. Study with someone else or study something else.'

1. It can be argued against the formalist account of JP (see Videtur quod, 2.) that since there is no Jewish physics, no Jewish biology and no Jewish sociology (being radically different from social studies on Judaism), there can be no JP. This is drastically canvassed by Jospe, saying that some Jews playing football doesn't make their playing

18 Stern, “Was jüdische Philosophie sein könnte (wenn es sie gäbe). Ein mediävistischer Blick,” 278 (emphasis added).

19 Cf. Stern, "What is Jewish Philosophy? A view from the Middle Ages," 186-190.

20 Ibidem, 198.

21 Ibidem, 201. 
football a Jewish football game. The formalist account of JP can be formalistically challenged also by the following example: Suppose that a philosopher discovers at the end of her career that she was Jewish. Would this 'retroactively turn' her work 'into a contribution to Jewish philosophy'?22 Taking the example of the late Hilary Putnam who towards the end of his life cared more and more about his 'Jewishness', does not mean that his earlier work becomes JP retrospectively.

2. According to the critical historiographical account of JP $\left(\mathrm{JP}_{\mathrm{CHA}}\right)$, JP was simply 'the creation of the academic discipline, the "History of Jewish Philosophy," an artefact made by an academic discipline as much as the discipline studies it. ${ }^{23}$ Within the camp of $\mathrm{JP}_{\mathrm{CHA}}$, however, there is an ongoing controversial debate on the origins of this 'artefact'. Whereas Leora Batnizky claims that JP is a 'modern academic construct, ${ }^{24}$ Daniel Frank traces the idea of its tradition back to nineteenth century German-Jewish Wissenschaft des Judentums. The Wissenschaft des Judentums sought to legitimate Jewish philosophical texts as a respected academic subject. ${ }^{25}$ I have shown that the idea of a philosophia judaeorum perennis is even older, stemming from seventeenth century French-German discourse on 'historiographical holism"26 and German Enlightenment historiography of Jewish Thought. ${ }^{27}$ Even prior to that, so Giuseppe Veltri argues, the 'first sketch of a Jewish [...] history of philosophy was formulated by the Venetian Rabbi Simone Luzzatto (1583-1663), ${ }^{28}$ consequently dating the 'artefact' of JP back into sixteenth century humanism.

3. In addition, $\mathrm{JP}_{\mathrm{CHA}}$ demonstrates that JP was not only a historiographical invention but also a highly polemical one. ${ }^{29}$ Within seventeenth and eighteenth century 'historiographical holism,' JP was introduced as an allegedly continuous tradition (from the prophets [= philosophia haebraeorum] up until Moses Mendelssohn) only in the end to be expelled from the kingdom of 'serious' philosophy. More bluntly: JP was invented for no other purpose than to be excluded as a mere philosophia extra-graecanica or philosophia orientali.

As a consequence, any essentialist account of JP has to question itself as to whether it wants-however unconsciously-to continue this polemical tradition of

22 Goltzberg, “Three Moments in Jewish Philosophy," 3.

23 Stern, "What is Jewish Philosophy? A view from the Middle Ages," 186.

24 Leora Batnizky, "The Nature and History of Jewish Philosophy," in Jewish Philosophy Past and Present, eds. Daniel H. Frank and Aaron Segal (New York and London: Routledge, 2016): 72.

25 Daniel Frank, “What is Jewish philosophy?,” in History of Jewish Philosophy, eds. Daniel H. Frank and Oliver Leaman (London: Routledge, 2004).

26 Dirk Westerkamp, Die philonische Unterscheidung. Aufklärung, Orientalismus und Konstruktion der Philosophie (München: Fink, 2009); cf. also idem, "The Philonic Distinction. German Enlightenment Historiography of Jewish Thought," History and Theory 47 (2008): 533-559.

27 Westerkamp, Die philonische Unterscheidung, 15-90.

28 Giuseppe Veltri,”Die arabische Philosophie und der Islam im modernen jüdischen Denken,” in Jewish Lifeworlds and Jewish Thought (FS Grözinger), ed. Nathanael Riemer (Wiesbaden: Harassowitz, 2012): 100.

29 Westerkamp, Die philonische Unterscheidung, 71-74. 
tradition-construction or not. If not, this would mean either to write a different history of the tradition of philosophia judaeorum perennis or to give up its very idea altogether. In sum: according to $\mathrm{JP}_{\mathrm{CHA}}$, there is no such category as JP prior to Early Modernity and, as a consequence, Philo or Maimonides never were (and never have or could have considered themselves to be) Jewish philosophers.

4. According to the anti-essentialist account of JP $\left(\mathrm{JP}_{\mathrm{AEA}}\right)$, JP is philosophically unoriginal; its philosophical issues, methods and solutions are second hand news. The 'philosophy' in JP is borrowed from philosophically genuine non-Jewish backgrounds: Greek thought, Islamic philosophy, scholastic thinking, and later (with regard to Moses Mendelssohn and Hermann Cohen) from Leibnizian or Kantian philosophy etc. In this sense, Veltri and others (Stern, Samuelson, Leaman etc.) argue that JP can not be conceived of independently from Arabic Muslim philosophy etc.; it can only be determined in 'interaction' (Wechselwirkung) with other philosophical cultures. Hence, JP can be studied only by taking into account the multifaceted and underlying processes of 'cultural transfer.' ${ }^{30}$ This position could be termed the culturalist anti-essentialist account of JP (JP $\left.\mathrm{PAEA}_{\mathrm{CA}}\right)$.

5. Even more radical, some interpreters claim the principal irreconcilability of Judaism and philosophy, the latter concerned with pure reason, the former stemming from religious experience. Alexander Altmann's $\mathrm{JP}_{\mathrm{AEA}}$ maintains the irreconcilability of reason and revelation (this is, according to Altmann, philosophy's central project in the mediaevum as well as in eighteenth century Enlightenment). Accordingly, it is

[...] futile to attempt a presentation of Judaism as a philosophical system. [...] Judaism is a religion, and the truths it teaches are religious truths. They spring from the source of religious experience, not from pure reason. ${ }^{31}$

Altmann's position can be labelled the irreconcilabilist anti-essentialist account of JP $\left(\mathrm{JP}_{\text {IAEA }}\right)$.

6. $\mathrm{JP}_{\mathrm{IAEA}}$ leads to yet another prominent anti-essentialist account of JP, the antiuniversalist account of JP $\left(\mathrm{JP}_{\mathrm{AUA}}\right)$. According to this view, doing JP is 'insular', 'parochial' - in all a 'particularistic' enterprise. Restricted to Jewish matters, JP has to give up the very 'universal concerns ${ }^{32}$ which construct the core of any serious thinking that may deservedly be called 'philosophy'. Thus, there can be no JP, or at least JP is not philosophy for it does not exhibit a 'universal curiosity and a universal questioning ${ }^{33}$ into the foundations of existence. Likewise, Veltri argues that the epithet 'Jewish' restricts philosophy to particularistic (historical and cultural contingent) in-

30 Veltri, "Die arabische Philosophie und der Islam im modernen jüdischen Denken." 31 Alexander Altmann, "Judaism and World Philosophy," in The Jews: Their History, Culture, and Religion, ed. L. Finkelstein (Philadelphia: Jewish Publication Society of America, 1949): 954.

32 Tirosh-Samuelson/Hughes, "Editors' Introduction to Series," x.

33 Leon Roth, "Is there a Jewish philosophy?," in Jewish Philosophy and Philosophers, ed. R. Goldwater (London: Hillel Foundation, 1962): 8. 
terests, whereas philosophy (en sens large) has to 'go beyond the contingent. ${ }^{34} \mathrm{JP}_{\mathrm{AUA}}$ leads to the separation of general philosophy and Judaism. According to Leon Roth, there can be no such thing as JP may be a 'philosophy of Judaism' whereas conceivable: as 'the thinking and rethinking of the fundamental ideas involved in Judaism and the attempt to see them fundamentally, that is, in coherent relation one with another so that they form one intelligible whole. ${ }^{35}$

7. $\mathrm{JP}_{\mathrm{AUA}}$ has led to yet another position: the paradoxical or self-contradictory conception of JP ( $\left.\mathrm{JP}_{\mathrm{PARA}}\right)$ : JP somehow is and is not. According to Tirosh-Samuelson/ Hughes, Jewish philosophy is 'rooted in a paradox'-if not contradiction: 'As philosophy, this activity makes claims of universal validity.' Insofar as this activity is interpreted as a Jewish activity, philosophising becomes 'an activity by a well-defined group of people' and, therefore, 'it is inherently particularistic.' Hence, JP is ruled by a contradiction as the 'collision of particularistic demands and universal concerns. ${ }^{36} \mathrm{JP}$, then, would be a philosophical tradition (or stance) which heroically accepts the impossible task of trying to reconcile the irreconcilable: particularist faith and universalist reason, philosophical truths and religious practice. JP would accordingly be the heroic but (im)possible endeavour to at least try to bring the impossible into the form of philosophical discourse.

8. $\mathrm{JP}_{\mathrm{CHA}}, \mathrm{JP}_{\mathrm{AEA}}, \mathrm{JP}_{\mathrm{CAEA}}, \mathrm{JP}_{\mathrm{IAEA}}$, and $\mathrm{JP}_{\mathrm{AUA}}$ amount to the conclusion that (i) either there is no JP (as an essential or even formal entity) or (ii) that JP is an academic artefact or (iii) that JP is not possible (in terms of 'consistently conceivable')-or that JP is possible only as the philosophical possibility of facing and formulating the philosophically impossible $\left(\mathrm{JP}_{\mathrm{PARA}}\right)$.

\section{Responsio / Dicendum quod}

For the sake of the argument, I seek to take a dogmatist stance in the corpus articuli. Thus, I will-contre cœur (see Sed contra, 3.)-argue for an essentialist answer to the quaestio sceptica disputata. To do so, I will not only refute the Sed contra-theses but develop further decisive arguments which amount to a definition (or better: explication) of what JP was and is. Among these arguments are:

1. an argumentum ad verecundiam or argument from authority;

2. an empirico-transcendental argument against performative self-contradiction (which can be read as an argumentum ad hominem as well);

3. a pragmatic conceptual argument;

4. a methodological argument with regard to the distinction of scientific subject and object (implicitly rejecting the Sed-contra-arguments of $\mathrm{JP}_{\mathrm{CHA}}$ 2.-4.);

34 Veltri, "Die arabische Philosophie und der Islam im modernen jüdischen Denken," 99.

35 Roth, "Is there a Jewish philosophy?," 8.

36 Tirosh-Samuelson/Hughes, "Editors' Introduction to Series," ix-x. 
5. an anti-dogmatic tertium datur-argument with regard to the relation between reason and revelation (implicitly rejecting the Sed-contra-argument of $\mathrm{JP}_{\text {IAEA }} 5$.);

6. an anti-particularistic reductio ad-absurdum-argument (implicitly refuting the Sed contra-argument of $\mathrm{JP}_{\mathrm{AUA}} 6$.);

7. an anti-positivist argument in favour of a methodologically sound distinction between scientific subjects and literary categories (implicitly refuting the account of $\mathrm{JP}_{\mathrm{AUA}}$, namely Sed contra-arguments 1. and 7.);

8. a counterfactual classification-argument;

9. an argument from autonomy; and, finally, a

10. definition with the genus proximum 'philosophy' and three restrictive differentiae specificae.

It has to be said that (dicendum quod) there is a JP. This conclusion becomes evident (ex ergo patet) from the following arguments that serve as premises to the overall conclusion:

1. Eminent scholars work on medieval Jewish philosophy; other prominent scholars in the field have edited book series such as the "Library of Contemporary Jewish Philosophers" (Tirosh-Samuelson/Hughes). If we agree that these authorities are not 'bluffers' but actually know what they are doing, we must suppose that there is something that may be termed JP or $\mathrm{JT}^{37}$ or at least that there are indeed 'contemporary Jewish philosophers.'

2. There are chairs of Jewish Thought and Jewish Philosophy (Israel, US, Europe).$^{38}$ In Germany, there are, to the best of my knowledge, at least four chairs of JP or JT. ${ }^{39}$ Denying that there is such a thing as JP would be a performative contradiction for those occupying the chairs.

3. The existential copula 'is' in the question 'Is there a Jewish Philosophy?' does not refer to a quantificational-ontological question on 'what there is' (as Popperian

37 The difference between Jewish Philosophy (JP) and Jewish Thought (JT) may recall Heidegger's distinction between 'philosophy' and 'thinking' (Denken). Whereas 'philosophy' became a watereddown form of philosophy such as Betrieb or professionalised business, Heidegger favours 'thinking' (as 'real' philosophy) over philosophy; for him, 'thinking' stands in proximity/neighbourhood (Nachbarschaft) to poetry (Dichten). I trust that the difference between JP and JT does not imply the Heideggerian motive.

38 Just some random name-dropping: Paul Franks is Professor of Philosophy, Jewish Philosophy, and Religious Studies at Yale University; Benjamin Pollock is Sol Rosenbloom Chair in Jewish Philosophy and Associate Professor of Jewish Thought at the Hebrew University of Jerusalem; Haim Kreisel is Professor of Medieval Jewish Philosophy in the Department of Jewish Thought at Ben-Gurion University of the Negev; Noam Zohar is Associate Professor of Jewish Philosophy and Chair (General Philosophy) at Bar-Ilan University.

39 Jewish Philosophy and Religion: Giuseppe Veltri (Universität Hamburg); Religious Studies and Jewish Thought: Sina Rauschenbach (Universität Potsdam); Modern Jewish Philosophy: Walter Homolka (Universität Potsdam); Jüd. Philosophie und Geistesgeschichte: Frederek Musall (Hochschule für Jüdische Studien, Heidelberg). 
world 1-objects, for instance). Instead it refers to something that matters for us. It refers, moreover, to a category (a world 3-object/ideal object). These objects are not eternal but come into being through our scientific practices. JP is such a category. That it was 'invented' or is an 'artefact' ${ }^{\text {'0 }}$ does not mean that it does not matter for us now. The fact that Maimonides didn't regard himself as a Jewish philosopher (but as an Aristotelian philosopher and a pious Jew) because he didn't know of the artificial category 'JP' does not imply that he was not a Jewish philosopher.

4. There is a difference between doing JP (i.e. constituting/establishing the category itself) and doing research in the history of JP (i.e. always already using the category). Even if it may be that the history of JP was in fact an invention of the sixteenth- (Veltri), seventeenth/eighteenth- (Westerkamp), nineteenth- (Frank) or twentieth-century (Batnizky) scholarship and historiography, JP (as the subject of this scholarship) is not. This would mean that science and scholarship can sometimes produce their scientific objects. It is, however, a sign of good scientific practice to clearly distinguish the subject and object of science (the historian of nationalism need not to be a nationalist).

With the help of arguments 3./4., one can reject the Sed-contra-arguments of $\mathrm{JP}_{\mathrm{CHA}}$ (2.-4.).

Ad 2. Even historiographical artefacts and categories exist (in the sense that they matter, that they can be useful scientific objects) since the subject of these artefacts are series or bundles of existing texts by real authors. Traditions may be 'invented' but can nevertheless have a hold on us. JP is such a tradition.

Ad 3. Against the polemical classification of JP as non-philosophy (and the argument of $\mathrm{JP}_{\mathrm{CHA}}$ ), Jewish philosophers may invoke the 'counter-memory' (Jan Assmann) of their own tradition.

Ad 4. Against JP $\mathrm{AEA}_{\mathrm{AE}}$ 's argument of the 'non-originality' of JP ('borrowed' methods, rationalism etc.) one can show that in the history of philosophia perennis everyone borrows something from someone (so to speak). The scholastics thought highly of the Islamic and Jewish philosophical pioneer-work in metaphysics. Surely, cultural transfer is never a one-way street. Philosophical transfer always was a non-asymmetrical or a transitive relation. There has been an immense 'backflow' from JP to philosophy (especially to scholastic thinking).

5. $\mathrm{JP}_{\mathrm{AEA}}$ (see Sed contra, 5.) intends to develop an anti-dogmatist argument. Yet it is in itself highly dogmatic. The position according to which philosophy and Judaism or reason and revelation are irreconcilable, rests on a dogmatic a priori assumption. It follows the problematic logic of tertium non datur. And it shows a deep misunderstanding of JP. Contrary to that, Jewish philosophers like Maimonides tried to show that revelation is in itself rational. To say that religion is only irrational is in itself dogmatic, at best arrogant. In this vein, Horkheimer/Adorno argued that myths already have some inner rationality whereas pure and abstract reason can itself depra-

40 Stern, "What is Jewish Philosophy? A view from the Middle Ages," 186. 
vate into a myth and become a quasi-religious idol. So it seems that $\mathrm{JP}_{\mathrm{AEA}}$ 's view is not only dogmatic but extremely ahistorical and privileges a restricted modern view on historical matters.

6. Doing Jewish philosophy does not necessarily imply that it is 'insular', 'particularistic' or 'parochial', since being Jewish does not rule out (a) that this philosophy can at the same time be heavily influenced by Hellenistic, Islamic, Christian, hermeneutical, analytical, phenomenological or any other strand of thought. Denying that would ignore that, e.g., the medieval Jewish-philosophical enterprises were clearly intercultural and interreligious enterprises. ${ }^{41}$ And it does not rule out (b) that JP makes universal claims pertaining to every living creature. That is to say that philosophy can be particularistically Jewish without giving up its 'universal concerns' (Tirosh-Samuelson/Hughes).

If specifying epithets cause problems of particularism then this would also cast doubt on the possibility of any analytic, phenomenological or sceptical philosophy at all. Again, the sharp alternative between particularistic or universal philosophical claims rests on a problematic presupposition, on a binary opposition ruling out any third possibility. If any restriction of philosophy endangers its philosophical substance, then only ontology (as first philosophy) could be (absurdly) called philosophy.

With this argument, we may also refute Sed contra, 6. $\left(\mathrm{JP}_{\mathrm{AUA}}\right)$ : Every philosophy, every philosophical text (even Hegel's majestic, allegedly all-encompassing system) is somewhat particularistic. Any anti-universalist account of JP would have the burden of proof to show what instead could be a full-fledged universalistic account of philosophy. What is philosophically 'universal' at all? Hence, the argument against 'insularism' collapses into itself.

7. Universalism and particularism do not necessarily contradict. Something can universalistically be philosophy but particularistically be done in a Jewish garb; thus the analogy-if there a 22 Jews playing football it does not mean that what they do is Jewish football-does not hold; the same is true with 'Jewish physics' and the like. The analogy is bad since it contaminates two incomparable subjects. Philosophy is concerned with thoughts and arguments (expressed in speech and text) not primarily with natural objects. Since there can be a specific Jewish literature and a specific Jewish temple but no specific Jewish stone or planet, there can also be philosophical Jewish texts. Not to distinguish subjects and to convey the same passepartout-method on them is positivism or logical empiricism. Both are bad philosophy.

JP thus is a textual category. Edmund Husserl never produced a text which falls under this category but both the phenomenologist Emmanuel Lévinas and the analytic philosopher Hilary Putnam did.

41 Stern, "What is Jewish Philosophy? A view from the Middle Ages," 198. 
With this in mind, $\mathrm{JP}_{\mathrm{AUA}}$ - namely Sed contra, 1. and 7.-can be rejected: Ad 7. The view that Jewish philosophy is 'rooted in a paradox' is no Alleinstellungsmerkmal of JP but holds true also with regard to Islamic Philosophy (IP) and Christian Philosophy (CP) (e.g. Neo-Thomism).

Ad 1. The formalist view is wrong since it is not the Jew which makes philosophy Jewish but that is a certain sort (and tradition) of texts that makes a philosophical text belong to JP.

8. Let us consider some simple yes/no-cases. Was Salomon a Jewish philosopher? Not in a technical sense. Was Philo of Alexandria a Jewish philosopher? Definitely! Maimonides? He too! Was Spinoza a Jewish philosopher? Not so much the author of the Ethica but rather the author of the Tractatus Theologico-Politicus. Husserl was not a Jewish philosopher, Lévinas was. Scholem was not, being a Jew but not a philosopher (calling himself a 'historian of religion'). Were Benjamin and Derrida Jewish philosophers? Difficult to say, at least not according to the definition with which this paper concludes. So here comes the eighth argument: What would we do if the historiographical category 'JP' were missing (or similar categories such as 'Islamic philosophy' or 'Christian philosophy')? How would we classify thinkers such as Maimonides, Crescas, Luzzatto? Thus, JP-if well-defined-seems to be a useful category.

9. As already seen, it is not a necessary condition for JP that an author interprets him- or herself as a Jewish philosopher in order to be one. This does not imply, however, that the self-attribution or self-understanding of authors is generally irrelevant. If some colleague came up to me and said, 'I am a Jewish philosopher'-who am I to disagree or tell he/she is not or he/she is a victim of a 'scientific self-misunderstanding' (Habermas). To a great extent, simply out of sheer respect, we would have to accept the autonomous philosophical self-interpretation of the other. If there were a group of philosophers calling themselves Jewish philosophers with good reasons to back this up, then they actually are Jewish philosophers that form the category 'JP'.

10. Without debating what 'philosophy' or 'philosophising' exactly means and reminding Nietzsche's insight that: we can only define that which has no history, the following definition (or less technically: explication) of the term JP can be given: JP is a philosophy of a specific historical tradition which philosophises out of the sources of Judaism, involves an account of the relation between reason and revelation and accepts (or in a weaker sense - reflects) the truth claims of the Jewish tradition as developed in the sources mentioned. Schematically:

JP is philosophy (or philosophising)

(genus proximum; genos)

- in a specific historical tradition ('-ish')

(species; eidos)

- ' 'out of the sources of Judaism' (H. Cohen) (i.e. Torah, Midrash, Talmud plus their commentaries)

$\left(1^{\text {st }}\right.$ differentia specifica)

- giving an account of the relation between reason and revelation $\quad\left(2^{\text {nd }}\right.$ differentia specifica) 
- $\quad$ accepting (or at least: reflecting) the truth claims of Jewish tradition developed in the mentioned sources (truth claims: One God, importance of prophecy, liability of the Halakhah etc.)

$\left(3^{\text {rd }}\right.$ differentia specifica)

Some explanations of the differentiae specificae or sufficient conditions/restrictions may be useful. Ad $1^{\text {st }}$ differentia specifica: The 'sources' of Judaism (however that category is defined) may in themselves already contain 'philosophemata' or 'theologoumena' or any elements prone to philosophical thinking. Ad $2^{\text {nd }}$ differentia specifica: Whatever 'reconciliation' means-it has to work with an 'update' of a certain philosophical terminology developed in former (Late-Antiquity, Mediaeval, or Enlightenment period) discourses on the topic. Ad $3^{\text {rd }}$ differentia specifica: A crucial, yet extremely difficult question is whether one has to fully accept the truth claims of the Jewish texts or may one adopt a neutral stance towards them when doing JP. My understanding is that one has to fully subscribe to these truth claims in order to write a JP. However, one could further distinguish between the attempt to ground the truth claims and to show how and why they are possible (i.e. moderate foundationalist position) and the attempt to show that they are not only grounded but that they are necessary and therefore have to be affirmed in toto (i.e. fundamentalist position).

From all this we may draw the conclusion: If it can be proved that there are authors and texts satisfying the conditions of this (internally open) definition, then there is JP. 